\title{
Influence of bacterial metabolites from permafrost on morphophysiological parameters of potato material in vitro*
}

\author{
N.O. Renev", E.S. Rodina, A.M. Subbotin, and V.A. Malchevskiy \\ Federal State Institution Federal Research Centre Tyumen Scientific Centre of Siberian Branch of the \\ Russian Academy of Sciences, Tyumen, Russian Federation
}

\begin{abstract}
The effect of secondary metabolites of bacteria from permafrost rocks on the in vitro morphophysiological parameters of potato microplants has been studied. Microplants of Zhukovsky ranniy potato variety were used as the object of the study. The experimental results indicate that when potato microplants are grown in vitro together in the Murashige-Skoog nutrient medium with the bacteria metabolites of the Bacillus cereus 9-08-CH9 and Achromobacter spanius 10-50TS2 strains introduced at the grafting time at a dose of $250 \mu$ l, they have the highest inhibitory effect. Secondary metabolites of these bacterial strains have a significant increase in the number of internodes at all stages of plant cultivation, which can accelerate the in vitro replication of material for original potato seed production. Metabolites of the bacterial strain Bacillus cereus 875TS in the indicated concentrations cause growth inhibition and delay in the development of microplants' root system at the initial cultivation stages.
\end{abstract}

\section{Introduction}

Cultivation of apical meristems with subsequent in vitro clonal micropropagation of plants is widely used in modern biotechnology [1]. In seed production, clonal micropropagation is mandatory in the production of healthy potato planting material. However, this method needs to be optimized to achieve a higher growth rate of microclones.

Currently in Russia and abroad, extensive research is being carried out to study the possibility of using beneficial forms of microorganisms to increase the agricultural crops' productivity and improve the quality of products [2-4].

Microorganisms can perform several functions: improving the plants' mineral nutrition, fixing atmospheric nitrogen, stimulating plant growth, suppressing phytopathogenic microflora, increasing plant resistance to stress $[5,6]$.

Strains of the Bacillus genus are one of the most common plant growth-promoting rhizobacteria (PGPR), which have antagonistic activity against several phytopathogens [7]. Bacillus genus has a great genetic diversity. Bacillus genus bacteria are present in a variety of environments from seawater to soil and even occur in extreme conditions such as hot springs [8]. In comparison with other types of bacteria, Bacillus spp. have a great advantage

${ }^{*}$ Corresponding author: solitary_72@mail.ru 
- they form endospores that are resistant to heating, drying, organic solvents, ultraviolet radiation, as well as produce various biologically active metabolites in addition to their abundance in the soil $[9,10]$. Bacillus genus bacteria possess such properties as auxins' production, dissolution of phosphates, nitrogen fixation, and biocontrol properties, which contribute to the growth and development of potatoes [11]. Studies by Singh N. et al. (2008) and Mehta P. et al. (2010) showed that Bacillus genus bacteria produce a significant amount of auxins in vitro, which stimulate the growth processes of plants [12, 13].

A collection of microorganisms isolated from permafrost rocks of Western and Eastern Siberia (Collection of soil microorganisms of permafrost rocks in the Arctic (SMPRA)) has been created at the Tyumen Scientific Center of the SB RAS. Using bacterial cultures from this collection, the research was carried out to study the influence of "relict" microorganisms on the morphophysiological, biochemical and cytogenetic indicators of modern biological objects of different organization levels from unicellular organisms to higher plants and animals. When testing several bacterial strains from permafrost on cultivated plants, it was shown that about $30 \%$ of them have a positive effect on the morphophysiological, biochemical and adaptive parameters of cultivated cereals and potatoes [14-20].

The purpose of this study was to assess the effect of secondary bacteria metabolites isolated from permafrost on the in vitro morphophysiological parameters of potato material.

\section{Materials and methods}

The study of secondary metabolites' effect was carried out on in vitro material of Solanum tuberosum L Zhukovsky ranniy variety bred by the Russian Potato Research Center.

Three strains of bacterial cultures were used in the work: Bacillus cereus 875 TS, Achromobacter spanius 10-50TS2 isolated from permafrost cores while drilling wells in the Tarko-Sale region (Russia, Yamalo-Nenets Autonomous District, Purovsky District); and Bacillus cereus 9-08- CH9 isolated from permafrost samples of coastal outcrops of the Chara River (Russia, Trans-Baikal Territory, Kalarsky District). The strains were identified by $16 \mathrm{~S}$ pPNA and deposited in the ARCIM FSUE State SRI Genetics (Moscow): 875TS (B-12242) - Bacillus cereus; 9-08-CH9 (B-12401) - Bacillus cereus; 10-50TS2 (B-12405) Achromobacter spanius. Cultivation of bacterial strains was carried out according to the procedure described below. Bacterial strains were inoculated into test tubes on a slant nutrient agar prepared by the standard method (GRM agar, Obolensk, TC 9398-020-78095326-2006) and cultured in a thermostat for 48 hours at $\mathrm{t}=26^{\circ} \mathrm{C}$. Then the microorganisms were washed out from each tube with $5 \mathrm{ml}$ of distilled water. The concentration of microorganisms was determined by the culture method of serial dilution by CFU amount on agar nutrient medium in Petri dishes [21]. After determining the number of bacterial cells in the original parent suspension, the cultures' density was brought to a working concentration of $1 \times 10^{9}$ microbial cells in $1 \mathrm{ml}$ of distilled water. Then the cell suspension was frozen for 8 hours at $\mathrm{t}-15^{\circ} \mathrm{C}$, after which it was thawed at $\mathrm{t}+22^{\circ} \mathrm{C}$ for 16 hours. The freeze-thaw cycle was repeated 3 times. According to the experimental data, this method doubles the yield of secondary bacteria metabolites into the aquatic medium. The total mass of peptide complexes in the filtrates amounted to $200 \mu \mathrm{g} / \mathrm{ml}$. The mass of peptide complexes was determined by the biuret method [22] and by preparative liquid chromatography on a Gilson chromatograph.

A sterile metabolites solution was obtained by filtering bacterial suspensions through Millipor filters with a pore diameter of $0.22 \mu \mathrm{m}$ (Durapore membrane filters, type $0.22 \mathrm{~mm}$ $\mathrm{GV}$ ). The obtained filtrates containing bacterial metabolites were used for further work. For studies to research the effect of bacterial metabolites on the potato meristem plants' development, metabolites in an amount (dose) of $250 \mu \mathrm{l}$ (50 $\mu \mathrm{g}$ for peptide complexes) were instilled (applied) onto the surface of the Murashige-Skoog culture medium poured into $5 \mathrm{ml}$ test tubes. In the control option, a filtered wash was added from the surface of nutrient agar 
in the same volume for microorganisms' cultivation. After 60 minutes, microscopic cuttings of potato plants were planted in these tubes.

In vitro propagation of potato material was carried out by the method of clonal micropropagation in accordance with the methodological recommendations for in vitro material replication for original potato seed production of Federal Research Center of Potatoes named after A.G. Lorkh [23]. The test tubes with the plants were placed in a special room with a temperature of $20-22^{\circ} \mathrm{C}$ and $5000-8000$ lux illumination with a photoperiod of 16 hours. The cultivation time was 30 days. The following morphological parameters were measured every 10 days: the number of internodes on the shoot, the shoot length, the number of roots on the plant, the maximum root length.

Statistical processing of the research results was carried out in accordance with international requirements using the "SPSS 11.5 for Windows" program for personal computers.

\section{Results and discussion}

Due to the evolutionary capacity for regeneration, the morphogenetic potential of the plant cell is manifested in a wider range than in natural conditions in vascular plants in in vitro systems. For potato crop, there are no specific recommendations in the methodological plan for assessing the in vitro morphogenesis of the material. Regeneration of biomaterial in tissue culture is recommended to be carried out in four phases: germination, intensive growth, slowed growth and natural death.

In the germination phase, the biomaterial is formed as a result of direct morphogenesis development since the formation of the root system and seedling occurs directly from the explant cells.

The most important part of the shaping process is the intensive growth phase. It is assessed in stages as morphological structures are formed: 2-3 internodes, 4-6 internodes and more than 7 internodes.

The phase of slowed growth begins when the standard parameters of the regenerant plants are reached. Standard plants include regenerants forming at least 4 internodes, dark green in color with a well-developed lamina and root system.

Physiological aging of the in vitro material begins with the phase of natural microplants' death. Its onset is usually observed from the moment of complete nutrient medium consumption and ends with the plants' drying or the formation of microtubers in vitro [23].

The influence of secondary bacteria metabolites on the in vitro morphophysiological parameters of potato material on day 10 is shown in Table 1.

Table 1. Influence of secondary bacteria metabolites on morphophysiological parameters of potato material in vitro on day 10 .

\begin{tabular}{|l|c|c|c|c|}
\hline \multicolumn{1}{|c|}{$\begin{array}{c}\text { Experimental } \\
\text { option }\end{array}$} & $\begin{array}{c}\text { Number of } \\
\text { internodes, } \\
\text { pcs. }\end{array}$ & $\begin{array}{c}\text { Plant } \\
\text { height, mm }\end{array}$ & \multicolumn{2}{|c|}{ Root formation } \\
\cline { 4 - 5 } & $2.70 \pm 0.15$ & $51.10 \pm 2.38$ & $5.10 \pm 0.48$ & $\mathrm{~mm}$ \\
\hline Control & $3.10 \pm 0.18^{*}$ & $55.10 \pm 2.36$ & $5.00 \pm 0.61$ & $55.44 \pm 2.47$ \\
\hline $\begin{array}{l}\text { Bacillus cereus 9- } \\
\text { 08-CH9 }\end{array}$ & $2.70 \pm 0.15$ & $57.00 \pm 2.85^{*}$ & $5.30 \pm 0.41$ & $52.31 \pm 2.77$ \\
\hline $\begin{array}{l}\text { Achromobacter } \\
\text { spanius 10-50TS2 }\end{array}$ & $2.20 \pm 0.16^{*}$ & $36.80 \pm 3.06^{*}$ & $3.30 \pm 0.30^{*}$ & $44.59 \pm 2.25^{*}$ \\
\hline $\begin{array}{l}\text { Bacillus cereus } \\
\text { 875TS }\end{array}$ & &
\end{tabular}

Note: * - reliability of differences between experiment and control $(\mathrm{p}<0.05)$. 
On the 10th day, in vitro microplants have a phase of intensive growth and they have formed an average of 2-3 internodes and up with a plant height from 36 to $57 \mathrm{~mm}$ and the number of roots of 3-6 pieces per plant. When treating potato microplants with bacteria metabolites of 9-08-CH9 Bacillus cereus strain, there was a significant $(p<0.05)$ excess of the number of internodes by $14.8 \%$ compared to the control. Bacteria metabolites of the Achromobacter spanius 10-50TS2 strain had a significant effect on plant height $(11.5 \%)$. Bacteria metabolites of the Bacillus cereus 875TS strain at the indicated concentrations caused a significant growth inhibition and a root system development delay of potato microplants.

Influence of secondary bacteria metabolites on the in vitro morphophysiological parameters of potato material on day 20 is shown in Table 2.

Table 2. Influence of secondary bacteria metabolites on in vitro morphophysiological parameters of potato material on day 20 .

\begin{tabular}{|l|c|c|c|c|}
\hline Experimental option & $\begin{array}{c}\text { Number of } \\
\text { internodes, } \\
\text { pcs. }\end{array}$ & $\begin{array}{c}\text { Plant height, } \\
\mathrm{mm}\end{array}$ & \multicolumn{2}{|c|}{ Root formation } \\
\cline { 4 - 5 } & $4.10 \pm 0.16$ & $61.90 \pm 2.19$ & $5.90 \pm 0.59$ & $\mathrm{~mm}$ \\
\hline Control & $4.50 \pm 0.13^{*}$ & $66.30 \pm 2.48$ & $5.70 \pm 0.60$ & $75.28 \pm 3.06^{*}$ \\
\hline $\begin{array}{l}\text { Bacillus cereus 9-08- } \\
\text { CH9 }\end{array}$ & $4.70 \pm 0.11^{*}$ & $67.50 \pm 2.59^{*}$ & $5.50 \pm 0.50$ & $70.98 \pm 3.75$ \\
\hline $\begin{array}{l}\text { Achromobacter } \\
\text { spanius 10-50TS2 }\end{array}$ & $3.40 \pm 0.17^{*}$ & $57.30 \pm 2.37^{*}$ & $4.50 \pm 0.56^{*}$ & $58.48 \pm 3.34^{*}$ \\
\hline Bacillus cereus 875TS & &
\end{tabular}

Note: * - reliability of differences between experiment and control $(\mathrm{p}<0.05)$.

According to table 2, it can be seen that on day 20 in vitro microplants reached standard parameters in the control option and in options with bacterial strains Bacillus cereus 9-08CH9 and Achromobacter spanius 10-50TS2. Microplants treated with secondary metabolites of the bacterial strain Achromobacter spanius 10-50TS2 significantly $(\mathrm{p}<0.05)$ exceeded the indices of the control microplant in the number of internodes by $14.6 \%$ and in plant height by $9 \%$; the bacteria metabolites of the Bacillus cereus strain 9-08-CH9 had a significant effect on the number of internodes $(9.8 \%)$ and root length $(11.8 \%)$. Microplants treated with secondary bacteria metabolites of the Bacillus cereus $875 \mathrm{TS}$ strain on day 20 did not reach the standard parameters and the morphometric parameters of these plants were significantly lower than those of other experimental options.

Influence of secondary bacteria metabolites on in vitro morphophysiological parameters of potato material on day 30 is shown in Table 3.

Table 3. Influence of secondary bacteria metabolites on in vitro morphophysiological parameters of potato material on day 30 .

\begin{tabular}{|l|c|c|c|c|}
\hline Experimental option & \multirow{2}{*}{$\begin{array}{c}\text { Number of } \\
\text { internodes, } \\
\text { pcs. }\end{array}$} & \multirow{2}{*}{$\begin{array}{c}\text { Plant height, } \\
\mathrm{mm}\end{array}$} & & \multicolumn{2}{|c|}{ Root formation } \\
\cline { 4 - 5 } & $5.20 \pm 0.22$ & $87.40 \pm 2.13$ & $6.30 \pm 0.45$ & $\mathrm{~mm}$ \\
\hline Control & $6.20 \pm 0.24^{*}$ & $90.20 \pm 2.69$ & $6.00 \pm 0.30$ & $79.47 \pm 3.01$ \\
\hline $\begin{array}{l}\text { Bacillus cereus 9-08- } \\
\text { CH9 }\end{array}$ & $6.80 \pm 0.29^{*}$ & $85.80 \pm 2.52$ & $5.90 \pm 0.42$ & $74.25 \pm 3.86$ \\
\hline $\begin{array}{l}\text { Achromobacter } \\
\text { spanius 10-50TS2 }\end{array}$ & $5.70 \pm 0.30$ & $76.20 \pm 3.04^{*}$ & $5.50 \pm 0.52$ & $67.48 \pm 3.45^{*}$ \\
\hline Bacillus cereus 875TS & &
\end{tabular}

Note: * - reliability of differences between experiment and control $(\mathrm{p}<0.05)$.

According to table 3, it can be concluded that on day 30 all microplants have reached standard parameters; a phase of slow growth is observed. In comparison with the control, 
significant $(\mathrm{p}<0.05)$ differences in the number of internodes were observed in microplants treated with secondary metabolites with bacterial strains Bacillus cereus 9-08-CH9 and Achromobacter spanius 10-50TS2. Microplants treated with secondary bacteria metabolites of the Bacillus cereus 875TS strain achieved control values for the number of internodes and the number of roots but had significant differences in plant height and root length.

\section{Conclusions}

The experimental results indicate that when potato microplants are grown in vitro together in the Murashige-Skoog nutrient medium with the bacteria metabolites of the Bacillus cereus 9-08-CH9 and Achromobacter spanius 10-50TS2 strains introduced at the grafting time at a dose of $250 \mu \mathrm{l}$, they have the highest inhibitory effect. Secondary metabolites of these bacterial strains have a significant increase in the number of internodes at all stages of plant cultivation, which can accelerate the in vitro replication of material for original potato seed production.

Metabolites of the bacterial strain Bacillus cereus 875TS in the indicated concentrations cause growth inhibition and delay in the development of microplants' root system at the initial cultivation stages.

\section{Acknowledgements}

*The work was carried out according to state order No. 121041600036-6

\section{References}

1. E.F. George, P.C. Debergh, Plant Propagation by Tissue Culture, 1, 29-64 (2008) doi: 10.1007 / 978-1-4020-5005-3

2. A.R. Devi, R. Kotoky, P. Pandey, G.D. Sharma, Bacilli and Agrobiotechnology (2016) https://doi.org/10.1007/978-3-319-44409-39

3. K.Y. Kargapolova, G.L. Burygin, O.V. Tkachenko et al., Plant Cell Tiss Organ Cult., 141, 351-359 (2020) https://doi.org/10.1007/s11240-020-01791-9

4. O.V. Tkachenko, N.V. Evseeva, N.V. Boikova, et al. Agron. Sustain. Dev 35, 11671174 (2015) https://doi.org/10.1007/s13593-015-0304-3

5. S.V. Timofeeva, Investigation of biotic and abiotic factors' role in the survival of induced bacteria at the first stages of plant ontogenesis: Thesis of diss. Cand. of Bio. Sci., 27 (2000)

6. Y. Bashan, Plant Soil., 1-33 (2014)

7. G. Santoyo, C. Orozco-Mosqueda Mad, \& M. Govindappa, Biocontrol Science and Technology, 22(8), 855-872 (2012)

8. J.A. Hoch, Journal of Cellular Biochemistry, 51, 55-61 (1993)

9. N. Sadfi, M. Cherif, I. Fliss, A. Boudabbous, \& H. Antoun, Journal of Plant Pathology, 83, 101-118 (2001)

10. B.J. Jacobsen, N.K. Zidack, \& B.J. Larson, Phytopathology, 94, 1272-127 (2004)

11. M. Senthilkumar, K. Swarnlakshmi, V. Govindasamy, Y.K. Lee, \& K. Annapurna, Current Microbiology, 58, 288-293 (2009)

12. N. Singh, P. Pandey, R.C. Dubey, \& D.K. Maheshwari, World Journal of Microbiology and Biotechnology, 24, 1669-1679 (2008) 
13. P. Mehta, A. Chauhan, R. Mahajan, P.K. Mahajan, \& C.K. Shirko, Current Science, 98(4), 538-542 (2010)

14. A.M. Subbotin, M.V. Narushko, E.O. Simonova, In the collection: Arctic, Subarctic: mosaic, contrast, variability of the cryosphere. Proceedings of the International Conference, 372-374 (2015)

15. A.M. Subbotin, M.V. Narushko, N.A. Bome, S.A. Petrov, V.A. Malchevskiy, M.A. Gabdullin, Vavilov Journal of Genetics and Breeding, 20(5), 666-672 (2016)

16. M.V. Narushko, A.M. Subbotin, A.S. Bazhin, S.A. Petrov, V.A. Malchevskiy, International Conference "Permafrost in XXI Century: basic and applied researches", 106-107 (2015)

17. A.M. Subbotin, M.V. Narushko, N.A. Bome, S.A. Petrov, V.A. Malchevskiy, M.A. Gabdullin, Vavilov Journal of Genetics and Breeding, 20(5), 666-672 (2016) DOI 10.18699/VJ16.119

18. A.M. Subbotin, A.S. Nurpeisova, M.V. Narushko, In the collection: International scientific and practical conference dedicated to the 131st anniversary of the birth of academician N.I. Vavilov, 94-96 (2018)

19. N.O. Renev, V.A. Malchevskiy, A.M. Subbotin, Materials of the XVI International Scientific and Practical Conference "Biologically active preparations for plant growing: scientific justification - recommendations - practical results", 2020

20. N.O. Renev, A.M. Subbotin, M.V. Narushko, V.A. Malchevskiy, IOP Conf. Ser.: Earth Environ. Sci. 699, 012017 (2021)

21. P. Gerhardt, Manual of methods for general bacteriology, 443-445, (1981)

22. R.M.C. Dawson, D.C. Elliott, W.H. Elliott, K.M. Jones, Data for Biochemical Research, (1986)

23. E.V. Oves, B.V. Anisimov, Guidelines for in vitro replication of material for original potato seed production, 25 (2017) 